\title{
PARAMETERS OF CASTLE FORTIFICATIONS ON THE TERRITORY OF THE WESTERN REGIONS OF UKRAINE OF THE MIDDLE OF THE 16TH - BEGINNING OF THE 18TH CENTURIES
}

\section{PARAMETRY UMOCNIEŃ ZAMKOWYCH W POŁOWIE XVI - NA POCZATTKU XVIII WIEKU NA TERENIE ZACHODNICH OBWODÓW UKRAINY}

\section{Olha Okonchenko}

Ph. D. of architecture, Assoc. prof. ORCID: 0000-0001-7503-5679

Lviv Polytechnic National University, Institute of Architecture and Design

Department of Design and Architecture Fundamentals

\section{Ihor Okonchenko}

master's degree of architecture, senior teacher

ORCID: 0000-0002-1812-0006

Kyiv National University of Culture and Arts, Lviv branch Department of Art

\begin{abstract}
A comparative typological and metrological analysis of defensive structures of 53 castles in the western regions of Ukraine is carried out. Fortification lines of castles are classified, based on the division of fortresses by their dimensions, proposed in the treatise on fortification in 1659 by $\mathrm{J}$. Naronovich-Naronsky. The reasons for the functioning of castle fortifications with different levels of defense in one period are explained.
\end{abstract}

Key words: bastion, castle, fortifications, military architecture, tower.

\section{STRESZCZENIE}

Przeprowadzono porównawczą analizę typologiczną i metrologiczną umocnień obronnych pięćdziesięciu trzech zamków zlokalizowanych na terenie zachodnich obwodów Ukrainy. Sklasyfikowano linie umocnień zamkowych w oparciu o podział twierdz pod względem rozmiaru, zaproponowany w traktacie o fortyfikacjach 1659 roku przez Naronowicza-Narońskiego. Uzasadniono przyczyny funkcjonowania w tym samym okresie umocnień zamkowych o różnym poziomie obronności.

Słowa kluczowe: architektura obronna, basteja, bastion, baszta, fortyfikacja, zamek. 


\section{INTRODUCTION}

Castles are of great historical, cultural and artistic value, primarily as architectural monuments. On the territory of western regions ${ }^{1}$ of Ukraine more than a hundred castles are known, functioning as defensive objects in the middle of the $16^{\text {th }} \mathrm{c}$. - early $18^{\text {th }} \mathrm{c}$. Despite the significant number of works devoted to the topic of castle architecture, further general research on these objects remains relevant.

The period of the middle of the $16^{\text {th }} \mathrm{c}$. - early $18^{\text {th }} \mathrm{c}$. is characterized by the constant introduction of improvements in defense structures, which is associated with the rapid growth of power and capabilities of fire artillery and the improvement of siege tactics. Most of the castles in the western regions of Ukraine that have survived to our time were fortified or re-fortified during the last period of military operation of the castle. Based on our previous studies (Okonchenko O. 2015; Okonchenko O., Okonchenko I., 2017), we can say that four of these castles have preserved to our days the planning and volumetric-spatial structure of the perimeter of the line of fortifications, in 46 of them are fortifications with different levels of losses. In the rest, the contours of the fortification perimeter are preserved in the topography of the area, or nothing is preserved higher and at the level of the ground surface.

The study of the fortifications of earlier periods is impossible without isolating layers of the last period of military functioning.

The purpose of this study is to summarize information about the type of defense system and dimensions castle fortification lines to facilitate the search for analogues in the conservation and reproduction, as well as to supplement knowledge of the history of architecture.

\section{MATERIALS AND METHODS}

Numerous publications of Ukrainian and Polish researchers (most famous of which are the works by A. Cholowski (Cholowski A. 1892), H. Logvyn (Logvyn H. 1968), O. Matsuk (Matsuk O. 1997), R. Aftanazi (Aftanazi R. 1994-1997), Z. Pilarchyk (Pilarchyk Z. 1997), V. Pshyk (Pshyk V. 2008), J. Adamchyk (Adamchyk J. 2004) teach upon construction history of the castles and present data on the lost elements, reconstructions and demolitions, which makes it possible to picture various changes that were taking place in the defensive structures of some castles as well as their outer appearances at different stages of existence. In addition, some researchers (B. Gverken (Gverken B. 1960, 1984), Yu. Nel'hovsky (Nel'hovsky Yu. 1986), O. Hodovaniuk (Asieiev Yu., Vechersky V., Hodovaniuk O. 2003), Ya. Bohdanovsky (Bohdanovsky Ya. 1996), O. Plamenytska (Plamenytska O. 2012), L. Prybieha (Prybieha L. 2011)) raise a question concerning formative influence of defensive functions on the fortification of the castles. They offer variants of the castle classification depending on the type of defensive structure or defense system used. Numerous works are also devoted to individual castles, but there is still a lack of generalized research on castles in Ukraine.

To study the architecture of fortifications, 53 castles $^{2}$ were selected (Fig. 1), which meet the following selection criteria: a) documentary evidence of the establishment or modernization of the castle

\footnotetext{
${ }^{1}$ Territorial boundaries of the study cover modern administrative boundaries of five regions of Ukraine (Lviv, Volyn, Rivne, Ternopil, Ivano-Frankivsk regions). Our investygation is do not provide conclusions with reference to the historical territories of the Rzeczpospolita voivodships and follows modern administrative division, which is caused by the convenience carrying on (field survey to the most remote objects within one day on condition you move from Lviv).

${ }^{2}$ In the Lviv region castles in: Bilyi Kamin, Brody, Busk, Dobromyl, Zhovkva, Zvenyhorod, Zolochiv, Lviv (High Castle), Murovane (Lyashky Murovani), Olesko, Pidhirtsi, Pidtemne, Pomoryany, Svirzh, Stryj, Stare Selo, Yavoriv, Zvenyhorod. In the Ternopil region castles in: Berezhany, Budaniv, Buchach, Vyshnivets, Dolyna, Zaloztsi, Zbarazh, Zolotyi Potik, Kremenets, Kryvche, Kudryntsi, Mykulyntsi, Pidzamochok, Sydoriv, Oleksynets Staryj, Skalat, Terebovlia, Toky, Nyrkiv (Chervonograd), Chortkiv, Yahilnytsia, Yazlovets. In the Ivano-Frankivsk region castles in: Halych, Mariiampil, Pniv, Rakovec, Chernelytsia. In the Volyn region castles in: Lutsk, Volodymyr-Volynsky, Olyka. In the Rivne region castles in: Dubno, Klevan, Novomalyn, Ostroh, Stepan.
} 
fortifications in the studied period; b) the preservation of fragments of the lines of the castle fortifications, which are traced in the field, or the presence of documents with data on the lost fortifications, which allow to determine the type of fortifications and analyze their architectural and planning characteristics.

To identify the form of fortifications used in the studied castles, we took as a basis the theoretical ideal models: tower, tower, bastion and bastion defense systems, developed by the eminent Polish researcher Janusz Bogdanowski (Bohdanovsky J. 1996).

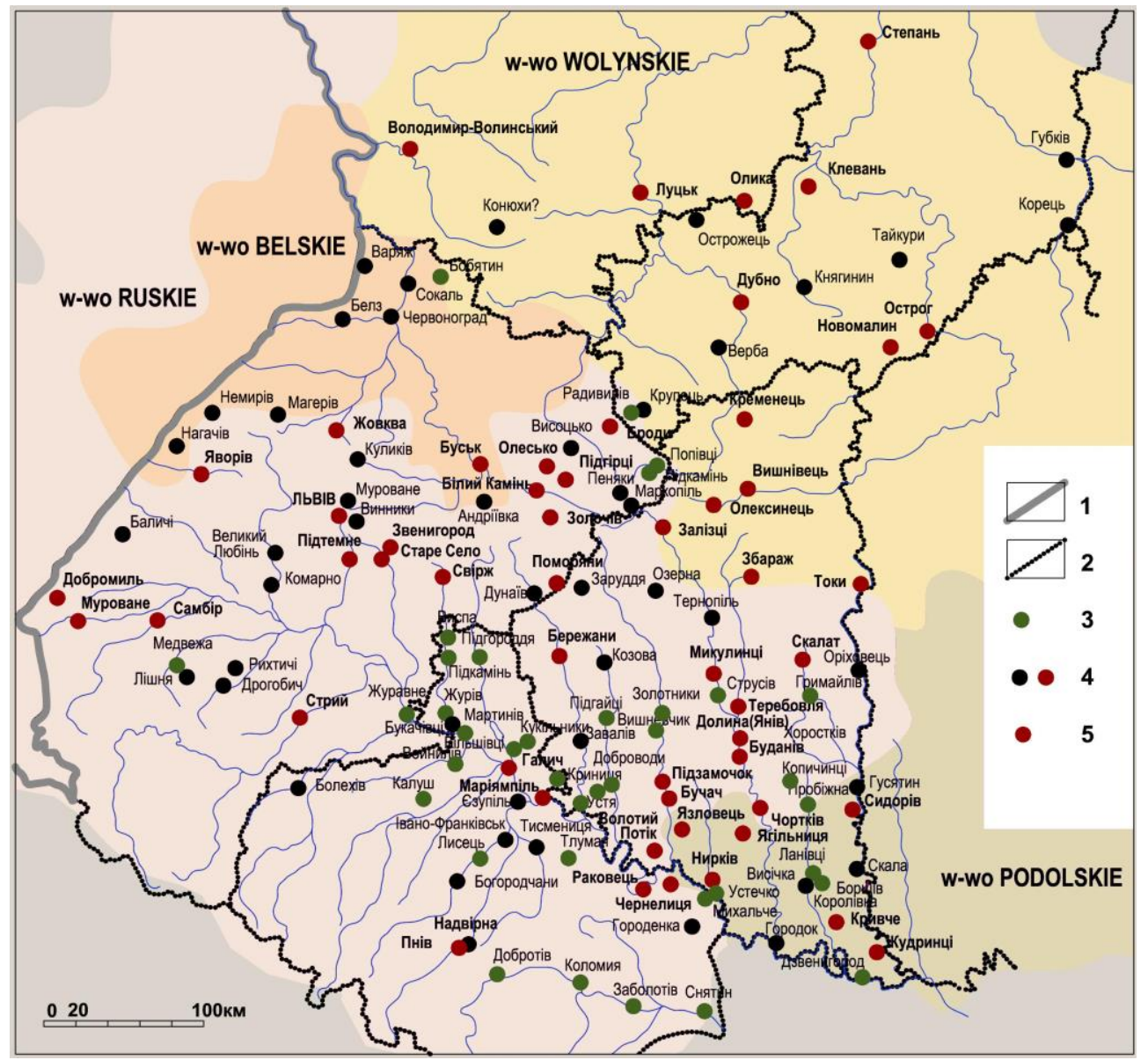

Fig. 1. The limits of the study. 1. Modern state border of Ukraine. 2. The boundaries of the investigated areas. 3. Castles on about which there is not enough data. 4. Castles that functioned in the second half of the $16^{\text {th }}-$ late $17^{\text {th }}$ C. 5. Castles selected for research.

Ryc. 1. Zakres badania. 1. Współczesne granice Ukrainy. 2. Granice terenu badanych obwodów. 3. Zamki, o których brak jest wystarczających danych. 4. Zamki, które funkcjonowały w drugiej połowie XVI - pod koniec XVII wieku. 5. Zamki wybrane do badania.

\section{RESULTS AND DISCUSSIONS}

\subsection{Classification of castle fortifications by the type of applied defense system}

As a result of the research, it was found out that (despite the fact that in the studied territories the appearance of the bastion system falls on the second half of the $16^{\text {th }} \mathrm{c}$.) at that time several castles had functioning lines of fortifications made in accordance with the principles of the turret system. 
These are the castles of Olesko, Lutsk, Volodymyr-Volynsky, Kremenets, the core of which was built by the middle of the 16th c. In the majority of the castles in the second half of the 16th c. - the first half of the 17th c. tower (flanking towers) and bastei (round bastion) defensive systems continue their development, though they are characteristic of the fortifications erected by the middle of the16th c. According to the principles of the tower system, there functioned fortifications of the castle core: 1 ) erected by the middle of the $16^{\text {th }} \mathrm{c}$. in Lyashki-Murovani, Svirzh, Chervonogorod; 2 ) those laid at the beginning of the $17^{\text {th }} \mathrm{C}$. in Kryvche and Kudryntsi.

According to the principles of the bastei (round bastion) system - these functioned fortifications of the core of castles: 1) laid by the middle of the $16^{\text {th }} \mathrm{C}$. and rebuilt in Pomoriany, Lviv, Ostroh, Stare Selo, Dobromyl, Halych, Pniv, Buchach, Terebovlia, Yazlovets, Mykulyntsi, Sydoriv, Budaniv, Berezhany, Dolyna, Klevan, Zaloztsi; 2) laid during the examined period in Bilyi Kamin, Toky, Oleksynets Stary, Chortkiv. Some of these castles are provided only with basteis, most of them as a result of modernization revealed application of flanking towers, basteis, early forms of bastions in one line of fortifications.

Most of the basteis (round bastions) of the studied castles were small and suitable for defense only by small arms and individual artillery units of small caliber from the upper terraces.

According to the principles of the bastion system, the fortifications of the 1st (closest to the castle core) and 2nd lines of castle fortifications functioned being divided into: 1) early forms of the bastion system (laid or thoroughly rebuilt in the late 16th - in the 30s of the 17th c. in Zhovkva, Zbarazh, Zolotyi Potik, Pidzamochok, Pidtemne, Novomalyn, Skalat, Yazlovets (2nd line), 2) classical bastion systems (laid or thoroughly rebuilt during the $17^{\text {th }} \mathrm{c}$. - the beginning of the $18^{\text {th }} \mathrm{c}$., in Brody, Olyka, Zolochiv, Chernelytsia, Pidhirtsi, Vyshnivets, Yahilnytsia, Halych, Dubno, Zvenyhorod, Lyashky Murovani (2nd line), Berezhany (2nd line), Mariampol (1st and 2nd line), Pomoryany (2nd line), Zhovkva (2nd line).

It has been proved that as a result of the reconstruction of the fortifications, in accordance with the rules of the schools of bastion architecture prevailing over time, various compromise options were implemented, different from the ideal solutions proposed by the theorists. The primary features characteristic of the old and new Italian schools are found in the fortifications of castles in Brody, Vyshnivets, Olyka, and Dubno. In accordance with the principles of the Old Dutch school, the fortifications of the castles in Zolochiv and Chernelytsia were fortified, the fortifications of the castle in Vyshnivets were modernized, and the second line of fortifications in the castles in Pomoriany and Berezhany was laid. From the second half of the $17^{\text {th }} \mathrm{c}$. the influences of the New Dutch and French schools are reflected in the modernized fortifications of the castles of Brzezany, Vyshnivets, Pomoriany, Stryj, Dubno and Olyka. At the same time, the fortification of the castle in Halych was modernized in the bastion system with the inclusion of tenal and cremation fronts. A combination of tenal and bastion fronts was also used in the castle in Yahilnytsia.

\subsection{Classification of castle fortifications by their dimensions}

Among the investigated castles we also find a significant difference in the dimensions of the fortification lines. In particular, in the castles with fortification lines in tower and bastion systems, the dimensions of the front between adjacent corners do not exceed 120 meters. In the lines of castle fortifications fortified according to the bastion system, the dimensions of the bastion front range from 60 to 350 meters (Fig. 2).

The geometric design, as an indicator of the perfection of the bastion system, was inextricably linked to the effective range for the destruction of firearms, which was reflected in the use of modules in the development of plans for defense structures (Bohdanovsky J. 1996 p. 107). That is, the calculation of the dimensions of the fortification lines depended on the planned value of the fortifications and armaments. For example, J. Naronovich-Naronsky in a treatise on fortification in 1659 wrote that "every lord has to build a fortress according to his wealth and prosperity. A large fortress can be built by a rich lord, a powerful prince, a king or at the expense of the Commonwealth. And the lords of the lower level can fortify their castles or courtyards with "half-reals or quarter-reals" (Naronowicz-Naroński J. 1957 p. 54) (Fig. 3). 

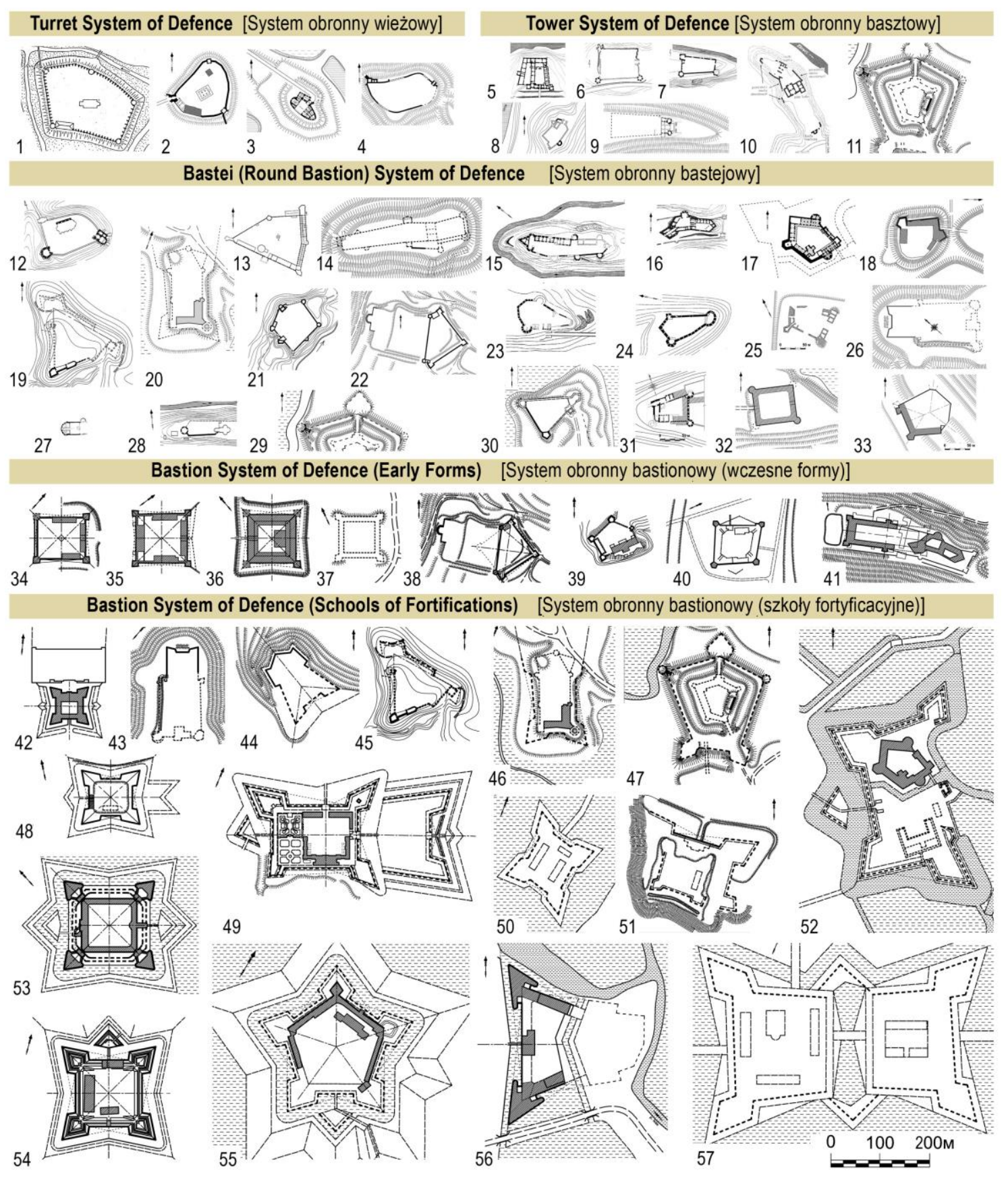

Fig. 2. Outlines of castles, reduced to a single scale. (Schemes of outlines of castles from works by J. Adamchyk (Adamchyk J. 2004), A. Cholowski (Cholowski A. 1892), B. Kolosok (Kolosok B. 1993), O. Okonchenko (Okonchenko O. 2015), T. Poliak (Poliak T. 1997). 1) Volodymyr-Volynsky, 2) Lutsk, 3) Olesko, 4) Kremenets, 5) Svirzh, 6) Kryvche, 7) Kudryntsi, 8) Rakovets, 9) Nyrkiv (Chervonogorod), 10) Skala Podilska, 11) Lyashky Murovani, 12) Ostroh, 13) Stare Selo, 14) Lviv, 15) Sydoriv, 16) Yazlovets, 17) Berezhany, 18) Klevan, 19) Halych, 20) Pomoryany, 21) Pniv, 22) Pidzamochok (west part), 23) Buchach, 24) Terebovlia, 25) Zaloztsi, 26) Oleksynets St., 27) Dobromyl, 28) Dolina, 29) Lyashky Murovani (2nd line), 30) Toky, 31) Budaniv, 32) Mykulyntsi, 33) Chortkiv, 34) Zolotyi Potik, 35) Zhovkva, 36) Zbarazh, 37) Pidtemne, 38) Pidzamochok, 39) Novomalyn, 40) Skalat, 41) Yazlovets (2nd line), 42) Pidhirtsi, 43) Oleksynets St. (gornverk), 44) Jagielnica, 45) Halych (2nd line), 46) Pomoryany (2nd line), 47) Lyashky Murovani (2nd line), 48) Chernelytsia, 49) Vyshnivets, 50) Stryj, 51) Mariiampil, 52) Berezhany (2nd line), 53) Olyka, 54) Zolochiv, 55) Brody, 56) Dubno, 57) Busk.

Ryc. 2. Zarysy zamków sprowadzone do tej samej skali (Schematy zarysów zamków z prac J. Adamchyka (Adamchyk J. 2004), A. Chołowskiego (Cholowski A. 1892), B. Koloska (Kolosok B. 1993), O. Okonchenko (Okonchenko O. 2015), T. Poliaka (Poliak T. 1997). 


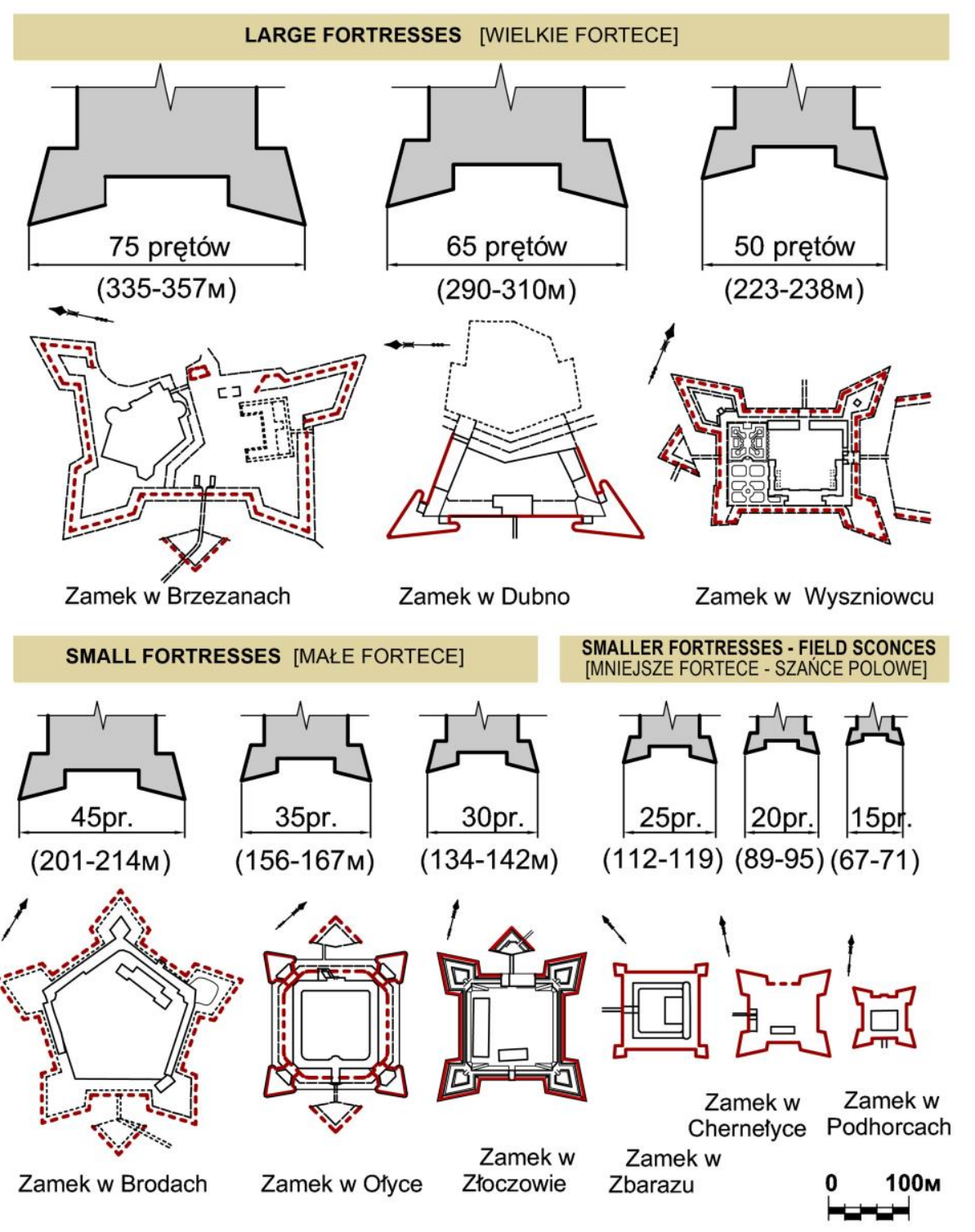

Fig. 3. Comparative scheme of outlines of bastion castles of Western Ukraine, distributed according to the classification subdivision of fortifications from the treatise of J. Naronovich-Naronsky (Naronowicz-Naroński J. 1957 p.).

Ryc. 3. Schemat porównawczy zarysów badanych zamków bastionowych, pogrupowanych zgodnie z podziałem klasyfikacyjnym umocnień z traktatu J. Naronowicza-Narońskiego (Naronowicz-Naroński J. 1957 p.).

According to this, J. Naronovich-Naronsky subdivides fortresses by size depending on the distance between the corners of the bastions into large fortresses (more than 45 rods), indicating that guns are required to defend these contour, small fortresses (45-30 rods) that can only be defended with muskets, and notes that fortresses smaller than 30 rods should be considered field sconces (fortifications) (Naronowicz-Naroński J. 1957 p. 69-71) ${ }^{3}$

Based on the comparison of the results of our metrological analysis of a number of castles with the classification division of fortresses by dimensions according to J. Naronovich-Naronsky, we conclude that large bastion fortresses include castles in Dubno, Berezhany, Busk - after the implemen${ }^{3}$ T. Novak, who studied the manuscript of J. Naronovich-Naronsky, states that the Polish rod is $4.466,541 \mathrm{~mm}$, the Rhine
rod, often used by the author, is 4. 766, $242 \mathrm{~mm}$, and the Dutch rod is 4.623,06 mm. (Naronowicz-Naroński J. 1957 p. 10). 
tation of their bastion fortifications in the second half of the $17^{\text {th }} \mathrm{c}$., castles in Olyka, Zolochiv, and Brody belong to small fortresses, and the nucleus of castle fortifications in Pidhirtsi, Zbarazh, Chernelytsia, Zhovkva, and Zolotyi Potik are sconces (Fig. 3). Therefore, among the bastion castles functioning at the investigated territory in the $17^{\text {th }} \mathrm{C}$. we come across a significant number of such castles which, according to the classification of J. Naronovich-Naronsky, are not large enough to be considered even small fortresses. Also, most of the castles, functioning according to the principles of the tower and bastion systems of organization of defense structures were not larger in size than the bastion sconces.
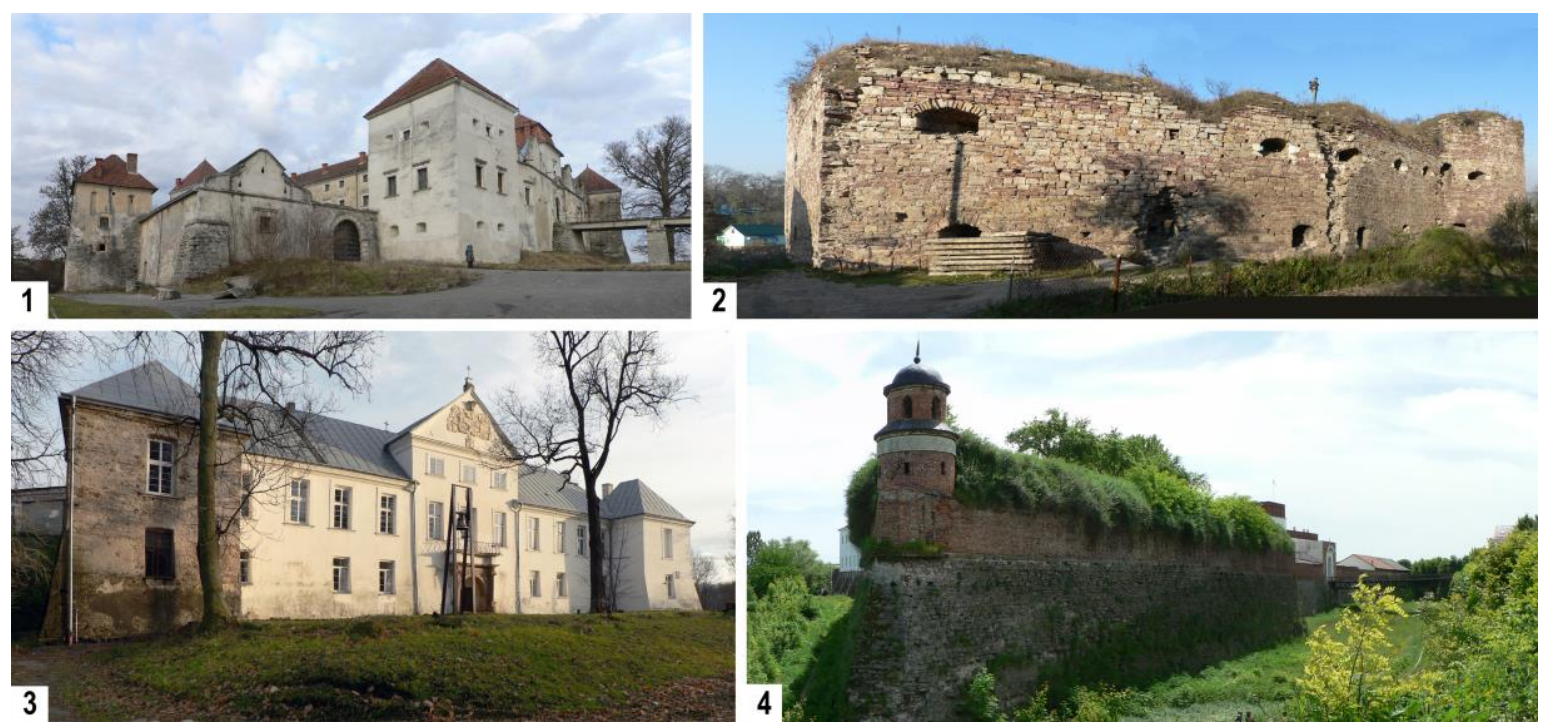

Fig. 4. Castles in 1) Svirzh (tower defensive system), 2) Buchach (bastei defensive system), 3) Yazlovets (2nd line) (early form of the bastion system), 4) Dubno (bastion system). Photo by O. Okonchenko

Ryc. 4. Zamki w 1) Świrzu (system basztowy), 2) Buczaczu (system bastejowy), 3) Jazłowcu (II linia) (wczesna forma systemu bastionowego), 4) Dubno (system bastionowy). Foto O. Okonchenko.

\subsection{Reasons for functioning of fortifications with different levels of defense}

The reason for building fortifications of different levels of defense was the interaction of such factors as the need to take into account the threat of attack of a probable enemy, the selection of effective counteraction to tactics and means of defeating potential enemies, the desire to find the most cost-effective solution. Corresponding to economic capability of the castle owner and predictable castle importance.

The Polish-Lithuanian Commonwealth was military arena throughout the $17^{\text {th }} \mathrm{c}$. The reason for this was both civil wars, uprisings, and wars with the Ukrainian Cossacks, Turkey, Sweden, Russia, ets. During this period, a prominent place among the means of destruction was given to fire artillery. In the Turkish, Russian, Swedish and Cossack armies, much attention was paid to artillery, so in the investigated areas, the bastion system of organization of defense structures was the best to ensured the viability of defense facilities. Bastion fortifications capable of resisting fire artillery (the range of which was constantly increasing) required the construction of additional external fortifications, which moved the main line of defense further away from the core of the castle. They could not function without a professional garrison and a sufficient number of weapons, especially the fortress artillery and its staff, the maintenance of which in the required number was not possible for all owners of land latifundia. At the same time, fortifications in the tower or bastion system were sufficient to protect the castle from the irregular army (Tatar detachments, insurgents, etc.). 
Among the monuments of defense architecture, many have gone down in history as fortresses strongholds for active warfare, but their current small size and lost defensive appearance do not explain how they could function in conditions where the defense needed to have a multilevel system of fortifications with hidden positions for the placement of means of fire and the ability to defend in the foreground area.

It is possible that such castles in the 17th c., had additional lines of fortifications that have not survived to our time, such as in the castle in Zbarazh, or they functioned in combination with the town fortifications as castles in Olyka, Brody, Brzezany, Zhovkva, Pomoriany.

In the $17^{\text {th }} \mathrm{C}$. the defense was held by external fortifications in the front, which did not allow the enemy to approach the walls of the fortifications. This is well illustrated by the historical plan of Zbarazh dating from the $17^{\text {th }}$ C. (Dybas B. 1998 p. 45), where it is stated that in addition to the fortifications of the castle core and thetown, several bastion lines around the castle and external fortifications, which covered large areas, were engaged in the fighting.

Therefore, we can assume that the castle in Chernelytsia, which according to the document from 1659 (Cholowski A. 1892 p. 75), Was considered a fortress and the preserved core of which corresponds in size to the size of the bastion trenches, in the $17^{\text {th }} \mathrm{c}$. was surrounded by fortifications that have not survived to our time. For the same reason, there are grounds to believe that the castle in Pidhirtsi, which has survived to our time, in the $17^{\text {th }} \mathrm{C}$. also formed the core of a complex multilevel system of fortifications. This is confirmed by the opinion of the Polish researcher of fortifications Jan Janczykowski, who, analyzing Pidhirtsi, notes: "so far there is a myth about the purely decorative nature of these fortifications, which is absurd due to the political situation in the country in the first half of the $17^{\text {th }}$ c." (Janczykówski J. 2004 p. 62).

Some castles, separated from the town due to the location on the dominant hill, at a certain stage of development of fortifications began to function as part of the system of urban fortifications. For example, the bastei castle in Buchach, separated from the town by steep banks and a river, undoubtedly functioned in a complex with the fortifications of the town, which in the 2nd half of the $17^{\text {th }} \mathrm{C}$. according to d'Aleirac's description of the town of Buchach "... was such an important and defensive city that Sultan Mohammed IV, after the capture of Kamyanets in 1672, came here in person for the siege" (Cholowski A. 1892 p. 72). High castle in Lviv with tower- bastei fortifications, which in the $16^{\text {th }} \mathrm{c}$. was not associated with the fortifications of the city center, in the 17th $\mathrm{c}$. was included in the common perimeter of the city's bastion fortifications and functioned as an integral part of the city's defense system.

\section{CONCLUSIONS}

After analyzing the applied types of defense systems and dimensions of castle fortifications, we came to the conclusion that in the investigated area in the $16^{\text {th }} \mathrm{c}$. there was a division of castles in accordance with the requirements for the defense of the castle depending on its importance, which explains the construction of fortifications with different levels of defense.

1) Castles, fortifications of which are built before to the period under study and in the middle of the 16 th c. - at the beginning of the 17th c. - brick fortifications in the tower, bastei (round bastion) and early forms of the bastion system, that were not able to withstand the siege artillery, but could operate independently, in defense of the Tatar army, individual detachments of Cossacks, Tatars or insurgents or operate in conjunction with urban fortifications ( castles in Svirzh, Kryvche, Kudryntsi, Buchach, Terebovlia, Yazlovets, Mykulyntsi, Budaniv, Lviv).

2) Castles, in which the effectiveness of bastion fortifications is maintained at the level of the latest achievements of Western European martial arts. They are designed to actively counteract heavy artillery. Being strong resist fortresses (without changing their social status of the castle) they could serve as a stronghold for active warfare (castles in Dubno, Berezhany, Busk, Olyka, Zolochiv, Brody, Zbarazh, Zhovkva, Zvenigorod). 
Analyzing the architecture of the preserved remains of castle fortifications, it is important to take into account that the castle core in the past could be part of a defense complex, which included both long-term fortifications and field erections during the war. This explains how the small size of the fortifications withstood the attack of the army armed with artillery.

\section{PARAMETRY UMOCNIEŃ ZAMKOWYCH W POŁOWIE XVI - NA POCZATKU XVIII WIEKU NA TERENIE ZACHODNICH OBWODÓW UKRAINY}

\section{WPROWADZENIE}

Zamki stanowią znaczną wartość historyczno-kulturalną i artystyczną, przede wszystkim jako zabytki architektury. Na terenie zachodnich obwodów Ukrainy ${ }^{4}$ znanych jest ponad sto zamków, które funkcjonowały jako obiekty obronne Rzeczypospolitej w połowie XVI - na początku XVIII wieku. Pomimo znacznej liczby prac poświęconych tematyce architektury zamkowej, dalsze uogólniające badania tych obiektów pozostają wciąż aktualne.

Okres połowy XVI - początku XVIII wieku charakteryzuje się ciągłym wprowadzaniem usprawnień w budowlach obronnych, co wiąże się z szybkim wzrostem mocy i możliwości artyleryjskich środków ogniowych oraz doskonaleniem taktyki oblężniczej. Większość z tych zamków, które przetrwały do naszych czasów, została ufortyfikowana lub dodatkowo ufortyfikowana właśnie w tym ostatnim okresie militarnego funkcjonowania zamku. Na podstawie naszych wcześniejszych badań (Okonchenko O. 2015; Okonchenko O., Okonchenko I., 2017) możemy stwierdzić, że tylko w czterech z tych zamków do naszych czasów została zachowana planistyczna i objętościowoprzestrzenna struktura linii umocnień, w kolejnych 46 występują umocnienia o różnym stopniu naruszenia. W pozostałych obiektach zarysy obwodu umocnień przetrwały w topografii terenu lub nic nie zostało zachowane powyżej i na poziomie powierzchni dziennej.

Badanie umocnień ze wcześniejszych okresów jest niemożliwe bez wyodrębnienia nawarstwień ostatniego okresu funkcjonowania militarnego.

Celem niniejszego badania jest uogólnienie informacji o rodzaju systemu obronnego oraz rozmiarach linii umocnień zamkowych w celu ułatwienia poszukiwania analogów podczas prowadzenia prac związanych z konserwacją i rekonstrukcją oraz uzupełnienia wiedzy z historii architektury.

\section{OBECNY STAN WIEDZY, METODYKA BADAŃ}

Liczne publikacje badaczy ukraińskich i polskich, z których najważniejsze to prace A. Chołowskiego (Cholowski A. 1892), H. Lohvina (Logvyn H. 1968), O. Matsiuka (Matsuk O. 1997), R. Aftanazego (Aftanazi R. 1994-1997), Z. Pilarczyka (Pilarchyk Z. 1997), J. Adamczyka (Adamchyk J. 2004), W. Pszyka (Pshyk V. 2008), wyświetlają historię budowy zamków i zawierają dane dotyczące utraconych elementów, przebudowy i zniszczeń, co pozwala na ukształtowanie wyobrażenia o różnorodności zmian, jakie zaszły w budowlach obronnych poszczególnych zamków oraz wyglądzie zamków na różnych etapach istnienia. Ponadto, niektórzy badacze (B. Gverken (Gverken B. 1960, 1984), Y. Nelhowski (Nel'hovsky Yu. 1986), O. Hodowaniuk (Asieiev Yu., Vechersky V., Hodovaniuk O. 2003), J. Bogdanowski (Bohdanovsky Ya. 1996),

\footnotetext{
${ }^{4}$ Zakres terytorialny badania - współczesne granice administracyjne pięciu obwodów Ukrainy (Iwowskiego, wołyńskiego, rówieńskiego, tarnopolskiego, iwanofrankiwskiego. Zakres terytorialny badania nie przewiduje wyciągania wniosków w odniesieniu do obszarów dawnych województw Rzeczypospolitej i jest zgodny ze współczesnym podziałem administracyjnym, co jest podyktowane dogodnością przeprowadzenia badania (a mianowicie lokalizacją najbardziej odległych obiektów w odległości jednego dnia drogi pod warunkiem wyjazdu ze Lwowa).
} 
O. Plamenytska (Plamenytska O. 2012), Ł. Prybieha (Prybieha L. 2011)) podnoszą kwestię kształtowania obronnych budowli zamkowych i podają wersje klasyfikacji zamków w oparciu o stosowane rodzaje budowli i systemów obronnych. Liczne prace poświęcone są również poszczególnym zamkom, jednak nadal odczuwalny jest brak uogólniających badań zamków położonych na terenie Ukrainy.

Do badania architektury fortyfikacji zostały wybrane 53 zamki ${ }^{5}$ (Ryc. 1), które spełniają kryteria wyboru: a) dokumentalne potwierdzenie założenia lub przebudowy umocnień zamku w badanym okresie; b) stan zachowania fragmentów linii umocnień zamkowych, które są czytelne w terenie lub dostępność dokumentów z danymi o zrujnowanych umocnieniach pozwalających na określenie rodzaju umocnień i przeprowadzenie analizy ich właściwości architektoniczno-planistycznych.

Do identyfikacji form fortyfikacji zastosowanych w badanych zamkach za podstawę przyjęliśmy teoretyczne idealne modele: wieżowego, basztowego, bastejowego i bastionowego systemu obronnego, które zostały opracowane przez wybitnego polskiego badacza Janusza Bogdanowskiego (Bohdanovsky J. 1996).

\section{PRZEBIEG PROCESU BADAWCZEGO}

\subsection{Klasyfikacja fortyfikacji zamkowych pod względem rodzaju zastosowanego systemu obronnego}

W wyniku przeprowadzonego badania stwierdzono, że mimo iż na badanych terenach pojawienie się systemu bastionowego przypada na drugą połowę XVI wieku, kilka zamków posiadało w danym okresie funkcjonujące linie umocnień wykonane zgodnie z zasadami systemu wieżowego. Są to zamki w Olesku, Łucku, Włodzimierzu Wołyńskim i Krzemieńcu, których umocnienia rdzenia wzniesione zostały w pierwszej połowie XVI wieku. W znacznej części zamków w drugiej połowie $X V I$ - pierwszej połowie XVII wieku kontynuują swój rozwój systemy basztowe i bastejowe, charakterystyczne dla umocnień powstałych do połowy XVI wieku, Zgodnie z zasadami systemu basztowego funkcjonowały umocnienia rdzenia zamków: 1) wzniesionych do połowy XVI wieku w Laszkach Murowanych, Świrzu, Czerwonogrodzie; 2) zbudowanych na początku XVII wieku w Krzywczach i Kudryńcach. Zgodnie z zasadami systemu bastejowego - umocnienia rdzenia zamków: 1) zbudowanych do połowy XVI i przebudowanych w Pomorzanach, Lwowie, Ostrogu, Starym Siole, Dobromilu, Haliczu, Pniowie, Buczaczu, Trembowli, Jazłowcu, Mikulińcach, Sidorowie, Budzanowie, Brzeżanach, Dolinie, Klewaniu, Załoźcach; 2) wzniesionych w badanym okresie w Białym Kamieniu, Tokach, Oleksińcu, Czortkowie. Niektóre z tych zamków wyposażone są jedynie w basteje, większość z nich w wyniku przebudowy otrzymała szereg baszt, bastei, wczesnych form bastionów w jednej linii umocnień. Większość bastei badanych zamków posiadała małe rozmiary i nadawała się do obrony jedynie ręczną bronią palną i poszczególnymi jednostkami artylerii małego kalibru z górnych tarasów.

Zgodnie z zasadami systemu bastionowego funkcjonowały fortyfikacje I (najbliższej do rdzenia zamku) i II linii umocnień zamkowych z podziałem na: 1) wczesne formy systemu bastionowego (wzniesione lub gruntownie przebudowane pod koniec XVI - w latach 30 XVII wieku w Żółkwi, Zbarażu, Złotym Potoku, Podzameczku, Podciemnie, Nowomalinie, Skałacie, Jazłowcu (II linia); 2) klasyczne systemy bastionowe (wzniesione lub gruntownie przebudowane w ciągu XVII - pierwszej połowie XVIII wieku) Brodach, Ołyce, Złoczowie, Czernelicy, Podhorcach, Wiśniowcu, Jagielnicy, Haliczu, Dubnie, Dźwinogrodzie, Laszkach Murowanych (II linia), Brzeżanach (II linia), Mariampolu (I i II linia), Pomorzanach (II linia), Żółkwi (II linia).

\footnotetext{
${ }^{5}$ Zamki w obwodzie Iwowskim: Biały Kamień, Brody, Busk, Dobromil, Żółkiew, Dzwinogród, Złoczów, Lwów (Wysoki Zamek), Murowane (Laszki-Murowane), Olesko, Podhorce, Podciemne, Pomorzyany, Świrz, Stryj, Stare Sioło , Jaworów; w obwodzie Tarnopolskim: Brzeżany, Budanów, Buczacz, Wyszniowiec, Dolina, Założce, Zbaraż, Złoty Potok, Krzemieńec, Krywcze, Kudryńce, Mykulińce, Podzameczek, Sidorów, Staryj Oleksiniec, Skałat, Terembowlia, Toki, Nyrkiw (Cherwonogród), Chortków, Yagielnica, Yazłowiec; w obwodzie iwanofrankiwskim: Halicz, Mariapol, Nadwórna, Pniów, Rakowiec, Chernelyca; w obwodzie wołyńskim: Łuck, Włodzimierz Wołyński, Ołyka; w obwodzie rówieńskim: Dubno, Klewań, Nowomalin, Ostróg, Stepań.
} 
Stwierdzono, że w wyniku przebudowy umocnień, zgodnie z zasadami konsekwentnie panującymi w dobie szkół architektury bastionowej, zrealizowane zostały różne kompromisowe warianty, odbiegające od idealnych rozwiązań proponowanych przez teoretyków. Pierwotne cechy charakterystyczne dla szkoły staro- i nowowłoskiej można zaobserwować w fortyfikacjach zamków w Brodach, Wiśniowcu, Ołyce, Dubnie. Zgodnie z zasadami szkoły staroholenderskiej wzniesiono umocnienia rdzenia zamków w Złoczowie, Czernelicy, zmodernizowano umocnienia zamku w Wiśniowcu, zbudowano II linię umocnień zamku w Pomorzanach i Brzeżanach. Od drugiej połowy XVII wieku wpływ szkoły nowoholenderskiej i francuskiej znajduje odzwierciedlenie w przebudowanych umocnieniach zamków w Brzeżanach, Wiśniowcu, Pomorzanach, Stryju, Dubnie i Ołyce. Wówczas zmodernizowano umocnienia zamku w Haliczu w systemie bastionowym z włączeniem frontów tenalnych i kremalierowych. Połączenie frontów tenalnych i bastionowych zastosowano również w zamku w Jagielnicy.

\subsection{Klasyfikacja fortyfikacji zamkowych pod względem rozmiarów umocnień}

Wśród badanych zamków znajdujemy również znaczną różnicę w rozmiarach linii umocnień. W szczególności, w zamkach z liniami umocnień w systemie basztowym i bastejowym wymiary dyszy między sąsiednimi narożnikami nie przekraczają 120 metrów. W liniach umocnień zamkowych ufortyfikowanych według systemu bastionowego wymiary frontu bastionowego wahają się od 60 do 350 metrów (Ryc. 2).

Konstrukcja geometryczna, która stała się wyznacznikiem doskonałości systemu bastionowego, była nierozerwalnie związana ze skutecznym zasięgiem broni palnej, co znalazło odzwierciedlenie w wykorzystaniu modułów przy opracowywaniu planów budowli obronnych (Bohdanovsky J. 1996 p.107). Oznacza to, że obliczenia wymiarów linii umocnień zależały od planowanego znaczenia umocnień i uzbrojenia. Na przykład, J. Naronowicz-Naroński w traktacie o fortyfikacjach z 1659 roku pisze, że „...tak też według możności $i$ dostatku swego ma pan kożdy fortece sobie budowac... Zgoła fortec głównych, realnych, potężnych nie zejdzie się budować, jakom wyżej spomniał, jeno albo panu barzo bogatemu, księciu możnemu, królowi, albo też kositem Rzeczypospolitej. Zaś fortece półreały, kwartreały etc. i tym podobne mogą sobie wystawiać mniejszej kondycyi panowie..." (Naronowicz-Naroński J. 1957 p. 54) (Ryc. 3). W związku z tym J. Naronowicz-Naroński dzieli twierdze pod względem rozmiarów w zależności od odległości między narożnikami bastionów na duże twierdze (których odległość między narożnikami wynosi ponad 45 prętów), wskazując, że do obrony tych narysów niezbędne są działa; małe twierdze (45-30 prętów), które można bronić tylko za pomocą muszkietów, i zauważa, że twierdze mniejsze niż 30 prętów powinny być uważane za szańce polowe ) (Naronowicz-Naroński J. 1957 p. 69-71)6.

$\mathrm{Na}$ podstawie zestawienia wyników przeprowadzonej przez nas analizy metrologicznej szeregu zamków z klasyfikacyjnym podziałem twierdz pod względem wymiarów według J. NaronowiczaNarońskiego, dochodzimy do wniosku, że do dużych twierdz bastionowych należą zamki w Dubnie, Brzeżanach, Busku - po realizacji w nich fortyfikacji bastionowych w drugiej połowie XVII wieku, do małych twierdz - zamki w Ołyce, Złoczowie, Brodach, do typu szańców - umocnienia rdzenia zamków w Podhorcach, Zbarażu, Czernelicy, Żółkwi, Złotym Potoku (Ryc. 3). Tak więc wśród zamków bastionowych, które funkcjonowały na badanym terenie w XVII wieku, obserwowana jest znaczna liczba takich, które według klasyfikacji J. Naronowicza-Narońskiego mają niewystarczające wymiary narysu, aby uznać je nawet za małe twierdze. Ponadto większość zamków, które funkcjonowały zgodnie z zasadami systemu wieżowego i bastejowego organizacji budowli obronnych, pod względem wymiarów nie były większe niż szańce bastionowe.

\subsection{Przyczyny funkcjonowania umocnień o różnym poziomie obrony}

Powodem budowy umocnień o różnych poziomach obrony było współdziałanie takich czynników jak konieczność uwzględnienia zagrożenia atakiem prawdopodobnego przeciwnika, dobór skutecznego przeciwdziałania taktyce i środków rażenia potencjalnych przeciwników, chęć odnalezie-

\footnotetext{
${ }^{6}$ Pręt - miara długości równa według J. Naronowicza-Narońskiego 10 stopom. Według T. Nowaka w XVIII w. w Polsce pręt wynosił 4.466,541 mm, pręt reński (użiwany często przez J. Naronowicza-Narońskiego) wynosił 4. 766, $242 \mathrm{~mm}$, pręt holenderski 4.623,06 mm (Naronowicz-Naroński J. 1957 p. 10).
} 
nia najbardziej korzystnego rozwiązania odpowiadającego możliwościom finansowym właściciela zamku i przewidywanego znaczenia zamku.

Przez cały XVII wiek Rzeczpospolita była areną nieustannych wojen. Powodem były zarówno wojny domowe, powstania, jak i wojny z Kozakami, Turcją, Szwecją, Rosją itp. W danym okresie poczesne miejsce wśród środków rażenia zajęła artyleria ogniowa. W armii tureckiej, rosyjskiej, szwedzkiej i kozackiej dużą wagę przywiązywano do artylerii, więc system bastionowy budowli obronnych najskuteczniej chronił żywotność obiektów obronnych położonych na badanych terenach. Umocnienia bastionowe zdolne do przeciwstawiania się artylerii ogniowej (której zasięg stale się zwiększał) wymagały budowy dodatkowych umocnień zewnętrznych, co przesuwało główną linię obrony coraz dalej od rdzenia zamku. Nie mogły one funkcjonować bez profesjonalnego garnizonu i wystarczającej ilości uzbrojenia, zwłaszcza artylerii fortecznej i jej obsługi, której utrzymanie w wymaganej liczbie nie było w siłach wszystkich właścicieli latyfundiów ziemskich. Z drugiej zaś strony, umocnienia w systemie basztowym lub bastejowym były wystarczające, aby bronić zamek przed nieregularnymi wojskami (oddziałami tatarskimi, powstańcami itp.).

Wśród zabytków architektury obronnej wiele przeszło do historii jako twierdze - punkty oporne do aktywnego prowadzenia wojny, jednak ich obecne niewielkie rozmiary i utracony wygląd obronny nie wyjaśnia, w jaki sposób mogły funkcjonować w warunkach, w których do obrony konieczne było posiadanie wielopoziomowego systemu umocnień z ukrytymi stanowiskami do rozmieszczenia środków rażenia ogniowego i możliwością prowadzenia obrony w strefie przedpola.

Niewykluczone, że takie zamki w XVII wieku posiadały dodatkowe linie umocnień, które nie zachowały się do naszych czasów, jak np. zamek w Zbarażu, lub funkcjonowały w połączeniu z umocnieniami miasta jak zamki w Ołyce, Brodach, Brzeżanach, Żółkwi, Pomorzanach.

W XVII wieku obrona była utrzymywana dzięki umocnieniom zewnętrznym na terenie przedpola, co nie pozwalało przeciwnikowi na zbliżenie się do murów umocnień. Dobrze ilustruje to plan historyczny Zbaraża z XVII wieku (Dybas B. 1998 p. 45), gdzie podano, że oprócz umocnień rdzenia zamku i miasta w działaniach wojennych wykorzystywano kilka linii bastionowych wokół zamku oraz umocnienia zewnętrzne, które obejmowały znaczne obszary.

Dlatego możemy założyć, że zamek w Czernelicy, który według dokumentu z 1659 roku uznawany był za twierdzę (Cholowski A. 1892 p. 75), i którego zachowany rdzeń pod względem wymiarów odpowiada wymiarom szańców bastionowych, w XVII wieku był otoczony umocnieniami, które nie przetrwały do naszych czasów. Z tej samej przyczyny są powody, by sądzić, że zamek w Podhorcach, który przetrwał do naszych czasów, stanem na XVII wiek stanowił także rdzeń złożonego wielopoziomowego systemu umocnień. Potwierdza to opinia polskiego badacza fortyfikacji Jana Janczykowskiego, który analizując Podhorce zauważa: „...natomiast funkcjonuje mif o rzekomym wyłącznie dekoracyjnym charakterze tych umocnień, absurdalny z uwagi na sytuacje polityczną kraju w 1. poł. XVII w." (Janczykówski J. 2004 p. 62).

Niektóre zamki, które zostały oddzielone od miasta ze względu na położenie na dominującym w okolicy wzgórzu, na pewnym etapie rozwoju fortyfikacji zaczęły funkcjonować jako element systemu umocnień miejskich. Na przykład zamek bastejowy w Buczaczu, odgrodzony od miasta stromymi brzegami i rzeką, niewątpliwie funkcjonował w połączeniu $z$ umocnieniami miasta, które w drugiej połowie XVII wieku, jak to opisywał Dalayrac ,...było tak ważnym i obronnym miastem, że sultan Mehmed IV po zdobyciu Kamieńca w 1672 roku przybył tu na oblężenie we własnej osobie" (Cholowski A. 1892 p. 72). Wysoki Zamek we Lwowie z fortyfikacjami basztowo-bastejowymi, który w XVI wieku nie był związany z umocnieniami śródmieścia, w XVII wieku został włączony do wspólnego obwodu miejskich fortyfikacji bastionowych i funkcjonował jako integralna część systemu obronnego miasta.

\section{WNIOSKI}

Po przeanalizowaniu zastosowanych rodzajów systemów obronnych oraz rozmiarów umocnień zamkowych stwierdzono, że na badanym terenie w XVII wieku nastąpił podział zamków zgodnie 
z wymaganiami, jakie stawiano obronie zamku w zależności od jego znaczenia, co tłumaczy budowę budowli obronnych o różnym poziomie obronności.

1) Zamki, których umocnienia zostały zbudowane przed badanym okresem i w połowie XVI - na początku XVIII wieku - murowane umocnienia w systemie basztowym, bastejowym i wczesnych formach systemu bastionowego, które nie są w stanie wytrzymać artylerii oblężniczej, ale mogą funkcjonować samodzielnie, podczas obrony przed wojskami tatarskimi, poszczególnymi oddziałami kozackimi, tatarskimi lub powstańcami, lub funkcjonują w połączeniu z umocnieniami miasta (zamki w Świrzu, Krzywczach, Kudryńcach, Buczaczu, Trembowli, Jazłowcu, Mikulińcach, Budzanowie, Lwowie).

2) Zamki, w których skuteczność umocnień bastejowych i bastionowych jest utrzymywana na poziomie najnowszych osiągnięć zachodnioeuropejskich sztuk walki, mają na celu aktywne przeciwdziałanie ciężkiej artylerii. Będąc mocnymi twierdzami (bez zmiany swojej społecznej istoty zamku) mogły służyć jako punkty oporu do aktywnego prowadzenia wojny (zamki w Dubnie, Brzeżanach, Busku, Ołyce, Złoczowie, Brodach, Zbarażu, Żółkwi, Dźwinogrodzie).

Analizując architekturę zachowanych pozostałości fortyfikacji zamkowych, należy wziąć pod uwagę, że rdzeń zamku w przeszłości mógł stanowić część kompleksu obronnego, który obejmował zarówno długotrwałe budowle fortyfikacyjne, jak i polowe, zbudowane podczas działań wojennych. To tłumaczy, jak niewielkie szańcowe rozmiary umocnień wytrzymały ataki armii uzbrojonej w artylerię.

\section{BIBLIOGRAPHY}

Adamchyk J., "Fortyficacje stałe na polskim przedmurzu od połowy XV do końca XVII wieku", Kielce : Wydaw. PŚ, 250 p., 2004.

Aftanazy R., "Dzieje rezydencji na dawnych kresach Rzeczypospolitey", Wroclaw: Vol. 5-9, 1994-1997.

Asieiev Yu., Vechersky V., Hodovaniuk O. ets. "Iсторія української архітектури" [History of Ukrainian architecture], edited by V. Timofienko. Kyiv: Technology, 472 p., 2003.

Bohdanovsky J., "Architektura obronna w krajobrazie Polski: Od Biskupina do Westerplatte", Warszawa ; Kraków: Wydaw. Nauk. PWN, 612 p.,1996.

Cholowski A., "Dawne zamki I twierdze na Rusi halickiej”, Teka konserwatorska. Lwow, pp. 65-132, 1892.

Dybas B. Fortece Rzeczypospolitey. Studium z dziejów budowy fortyfukacji stałych w państwie polsko-litewskim w XVII wieku, Toruń : Wydaw. T-wa naukowego, 1998. - $382 \mathrm{~s}$.

Gverken B., "Zamek Jazłowiecki. Sekcija Architektury I Urbanistyki. Studia i materiały do Teorii i Historii Arhitektury i Urbanistyki," Warszawa : Państ. wydaw. nauk., T. II., 165 p., 1960.

Gverken B., "Zamki w Polsce", Warszawa : Arkady, 348 p.,1984.

Janczykówski J. Zarys historii badan I konserwacji zabytkow - architektury obronnej w Polsce, Ohrona Zabytków. Krajowy Ośrodek Badań i Dokumentacji Zabytków. - Warszawa, 2004. - Nr 3/ 4. - S. 51-63.

Kolosok B. "Оборонні комплекси XVI-XVIIcm. Олики, Берестечка, Володимира-Волинського" [Defense complexes of the XVI-XVII c. by Olyka, Berestechko, Volodymyr-Volynsky ]. Матеріали конференції з проблем охорони фортифікаційних споруд в Україні, Кам'янецьПодільський, 1993. - С. 16.

Logvyn Н., "Стародавні мистецькі пам'ятки" [In Ukraine. Ancient art monuments], Kyiv : Mystetstvo, 462 p., 1968.

Matsuk О., "Замки і фортеці Західної України" [Castles and Fortresses of Western Ukraine], Lviv : Center of Europe, 160 p., 1997.

Naronowicz-Naroński J. "Budownictwo wojenne", Warszawa: Wydaw. Min. obrony narodowej, 1957. $-271 \mathrm{~s}$.

Nel'hovsky Yu., Hodovaniuk O., "Каменные замки западной Украины конца XVI - первой половины XVII вв." [Stone castles of western Ukraine at the end of the sixteenth - first half of 
the seventeenth century], Architectural Heritage, Moscow: Stroyizdat, iss. 34, pp. 125-133, 1986.

Okonchenko O., "Архітектура фортифікацій замків Західної України середини XVI - кінця XVII століть" [Architecture of Fortifications of Western Ukraine Castles in the Middle of the 16th - the end of the 17th centuries] Thesis abstract for Ph. D. in Architecture, speciality: 18.00.01, Lviv Polytechnic National University, Lviv, pp. 1-22, 2015.

Okonchenko O., Okonchenko I., "State of Preservation of the 16th - 17th Centuries Castle Fortifications on the Territory of Western Ukraine," Current issues in research conservation and restoration of historic fortifications. Collection of scientific articles. Number 9. ISSN 2544-6517. Chełm-Lviv: "Rastr 7", pp. 202-208, 2017.

Pilarchyk Z., "Fortyfikacje na ziemiach koronnych Rzeczypospolitej w XVII w.", Poznań : In-t historii UAM, 370 p. 1997.

Plamenytska O., “Castrum Camenecensis. Фортеця Кам'янець: (пізньоантичний ранньомодерний час)" [Castrum Camenecensis. Kamyanets Fortress: (late antique - early modern times)], Kamianets-Podilskyi : FOP Sysyn O.V, 672 p., 2012.

Poliak T. "Zamki na kresach. Bialorus, Litwa, Ukraina". Warszawa, Pracownia Badan i Konserwacji Obiektow Zabytkowych. Sp. z o.o., Druk. nauk.-Techn., wydaw. «Pagina». - 1997. - 224 s.

Prybieha L., "До питання типологічної класифікації мурованих замків України" [On typological classification of stone castles in Ukraine] Castles of Ukraine: research, preservation, use: materials international. Research Practice Conf., November 32011 - Halych, pp. 35-39, 2011.

Pshyk V., "Укріплені міста, замки, оборонні двори та інкастельовані сакральні споруди Львівщини XIII-XVIII ст." [Fortified cities, castles, defensive yards and defensive sacred buildings of the 13th-18th centuries in Lviv region], Lviv, 240 p., 2008.

\section{AUTHOR'S NOTE}

Okonchenko O., Ph. D. in Architecture, Assoc. prof. of the Lviv Polytechnic National University. In 2015 defended dissertation on " Architecture of Fortifications of Western Ukraine Castles in the Middle of the 16th - the end of the 17th centuries" Research interests: architecture of historical fortifications, design of subject-spatial environment. Theoretical experience is applied in design and research activities in the field of cultural heritage.

Okonchenko I., senior teacher of the Lviv branch Kyiv National University of Culture and Arts. Research interests: architecture of historical fortifications, design of subject-spatial environment. Theoretical experience is applied in design and research activities in the field of cultural heritage.

\section{O AUTORACH}

Okonchenko O. - w 2015 roku obroniła pracę doktorską na temat „Architektura fortyfikacji zamkowych na Ukrainie Zachodniej w połowie XVI - koniec XVII wieku". Zainteresowania naukowe: architektura historycznych fortyfikacji. Doświadczenia teoretyczne wykorzystuję w działalności projektowej i badawczej z zakresu ochrony zabytków.

Okonchenko I. - starszy wykładowca Iwowskiej filii Kijowskiego Uniwersytetu Narodowego Kultury i Sztuki. Zainteresowania naukowe: architektura historycznych fortyfikacji, projektowanie środowiska przedmiotowo-przestrzennego. Doświadczenia teoretyczne wykorzystuję w działalności projektowej i badawczej z zakresu ochrony zabytków.

Contact | Kontakt: oliaokonchenko@gmail.com; Iha.m.okonchenko@lpnu.ua 